\title{
The Role of Project-Based Language Learning in Developing Students' Life Skills
}

\author{
Dua' Ghosheh Wahbeh (D), Eman A. Najjar, Adel F. Sartawi, Maysa Abuzant and Wajeeh Daher * \\ Faculty of Educational Sciences, An-Najah National University, Nablus 44830, Palestine; \\ duawahbeh@gmail.com (D.G.W.); eman.alnajjar2010@gmail.com (E.A.N.); sartawi1975@gmail.com (A.F.S.); \\ m.abuzant@najah.edu (M.A.) \\ * Correspondence: wajeehdaher@najah.edu
}

Citation: Ghosheh Wahbeh, D.; Najjar, E.A.; Sartawi, A.F.; Abuzant, M.; Daher, W. The Role of ProjectBased Language Learning in Developing Students' Life Skills. Sustainability 2021, 13, 6518. https:// doi.org/10.3390/su13126518

Academic Editor: Clemens Mader

Received: 15 May 2021

Accepted: 4 June 2021

Published: 8 June 2021

Publisher's Note: MDPI stays neutral with regard to jurisdictional claims in published maps and institutional affiliations.

Copyright: (c) 2021 by the authors. Licensee MDPI, Basel, Switzerland. This article is an open access article distributed under the terms and conditions of the Creative Commons Attribution (CC BY) license (https:/ / creativecommons.org/licenses/by/ $4.0 /)$.

\begin{abstract}
Project-based learning is suggested for independent and collaborative learning that could positively impact students' learning. This study aimed to identify the role of project-based language learning in developing life skills of students through studying a case of a language class that included 80 students in two grade 6 classes in a private school. The study attempted to answer the following question: What is the role of project-based learning in developing students' life skills in an Arabic language class? To answer this question, we adopted a theoretical framework that included the following categories of life skills: personal and collaborative skills, self-orientation skills, and collective responsibility. The following three data collecting tools were used during the study: observation, semi-structured interviews, and the teacher and students' documents. Data collection lasted for two months from late September 2019 to December 2019. Data analysis followed the thematic analyses framework, by categorizing data into themes. The research results indicated that project-based learning helps to improve language students' personal and cooperative skills through developing their communication skills between themselves or with their teacher. In addition, project-based learning developed language students' mutual respect, their confidence, and their self-regulation of learning the Arabic language.
\end{abstract}

Keywords: project-based learning (PBL); language learning; life skills

\section{Introduction}

Today's world is constantly changing, which sometimes might leave a gap between what students learn in schools and what they actually need to survive in the real life. This puts schools under a lot of pressure to develop their educational instruction processes in an innovative manner [1,2] that help students to acquire and develop the needed life skills.

Life skills are defined as "abilities for adaptive and supportive behaviors that enable individuals to deal effectively with the demands and challenges of everyday life" [3] (p. 1). These skills can help individuals in leading a meaningful life [4]. Hence, it is of importance to consider the role schools play in equipping students with these life skills. Schools bear the responsibility of choosing the right strategies to develop these skills. One of these strategies is project-based.

Project-based learning (PBL) is a teaching strategy that offers students the chance to develop real life skills [5]. This occurs through engaging students in the cycle of PBL that requires the use of a variety of skills from the students to solve problems. This study aims to examine the role of PBL in developing life skills for sixth grade Arabic language students.

\subsection{Literature Review}

Life skills are part of 21st century education skills that have been advocated and divided into three types of skills by the author of [6]. The first is interpersonal and collaborative skills, which focus on the learner's ability to communicate, develop positive social relationships, and collaborate with others to achieve common goals. The second type 
is self-directed skills, addressing the learner's ability to identify learning goals, plan to achieve them, manage their time and effort, evaluate their learning outcomes and outputs, and identify their strengths and weaknesses. The third type is the skills of reliability and collective responsibility that focus on the ability of learners to take responsibility for their own learning, and classroom learning where each individual plays a role and students' roles are integrated with each other in achieving the goal. This division seemed convincing to many educators who found that the development of these skills could be motivated by applying learner-centered strategies such as project-based learning [7].

\subsubsection{Project Based Learning (PBL)}

John Dewey, with his works focusing on learning by doing, is regarded by some researchers as the founder of project-based learning. Dewey's theories on learning advocated a life-long learning approach where learning happens when students interact during real life tasks [8]. However, other researchers argue that the American philosopher Kilpatrick, a Dewey's successor, is the actual founder of project-based learning. Kilpatrick defines PBL as a set of meaningful activities in a social environment that focus on a specific content or on a theme $[9,10]$. As such, PBL focuses on learning by doing, experimenting, problem solving, teamwork, social skills, understanding, collaboration and partnership, and taking responsibility. The previous argument confirms that both Dewey and Kilpatrick played a major role in revolutionizing education. However, this does not deny the role of Vygotsky, the pioneer of social constructivist theory, in advancing project-based learning in schools. Social constructivist theory suggests that when taking part in educational projects, learners are given the opportunity to interact with their peers, exchange ideas, and ask questions, which helps them to develop their skills and gain new knowledge.

PBL is a vital teaching method that enables the satisfaction of different factors of social constructivist theory, especially collaborative learning and teacher's scaffolding. In addition, they encourage outdoor activities. Three factors have been described in the literature as contributing to students' learning [11-13], especially their autonomy and freedom to learn, to plan their learning, and to explore the content. Thus, these three factors point at project-based learning as part of sustainable education, as they lead to the development of students' life skills.

\subsubsection{Project-Based Learning (PBL) as Facilitator of Life Skills}

Project-based learning is consistent with different theories, such as social constructivist theory, which emphasizes that students build their knowledge by themselves when they work together with the teacher's guidance. Therefore, teachers should provide learning environments that allow students to take responsibility for their learning. Project based learning provides such environments, where students take responsibility for their learning and learn to develop their life skills through undertaking projects [14]. When individuals learn through social interactions when working in teams, collaborating and communicating to solve problems [15], they develop their life skills. Life skills are developed in these social contexts [16], where students take full responsibility for their learning [17] and learn new life skills that enhance their creativity and decrease the gap between knowledge and skills [18]. All of the previous points to project-based learning as a part of transformative education that leads to sustainable learning, and thus it serves students in their commitment to democratic society.

Moreover, project-based learning is consistent with multiple intelligence theory, as proposed by Gardner. Gardner differentiated the intelligences of learners and highlighted that all humans possess eight types of intelligence that are manifested in different skills and competencies; therefore, individuals learn differently to one another. Project-based learning accommodates different styles of learning by including different tasks. 
1.1.3. Project-Based Learning, Life Skills, and Transformative Environmental and Sustainability Education

Project-based learning and life skills could be related to transformative environmental and sustainability education. Bivens, Moriarty, and Taylor [19] argue that access to transformative education has a key role in overcoming the poor opportunities of marginalized children in society. Project-based learning constitutes an environment in which transformative education can occur as it provides a context for children to express their ideas, to plan, and to carry out their plans, in addition to looking back and trying to improve upon their initial plans. This is especially true in a context such as the Palestinian one, where a proportion of students are of low and middle socio-economic status. Walshe [20] report that an interdisciplinary approach encourages environmental and sustainability education. Besides, project-based learning could provide context for interdisciplinary learning [21], which points to it as encouraging sustainability education. Moreover, Öhman and Sund [22] propose a model that frames sustainability commitment. This model takes care of the intellectual, the emotional, and the practical aspects. It could be argued that project-based learning takes care of the three aspects, which suggests that project-based learning is related to a sustainability commitment. Furthermore, Fortune et al. [23] say that project-based learning constitutes a context in which university students experience transformative learning as they navigate a cultural learning journey, which results in the emergence of new insight into their own and others' subjective world views.

In addition to the facilitation of transformative education by project-based learning, transformative education could cultivate life skills. Lavrysh [24] argues that transformative learning is a factor that leads to the adoption of life-long learning. We argue that life-long learning interrelates with life competencies and skills. Anand and Anuradha [25] describe life skills as enhancing efforts to positively develop/change behavior related to healthy functioning in society. They found that it could provide education for the sustainable future of adolescent girls.

All of the previous literature emphasizes that project-based learning and life skills could be an important part of transformative environmental and sustainability education. This is specifically true of language education.

\subsubsection{Project Based Learning in the Language Classroom}

Researchers in language education are interested in factors that promote the development of language skills in general (e.g., [26,27]), and life skills in particular (e.g., [28]). Project-based learning could be one of these factors as, according to social constructivist theory, learning a language is a social and dynamic process that emphasizes the occurrence of learning when learners interact with each other. Therefore, PBL has a high probability of succeeding when used to teach and learn languages [29]. PBL works through the integration of language skills when students use the language to negotiate an authentic and real-life problem, as well as through working in groups and communicating to solve these problems. These activities provide students with opportunities to employ language in and outside the classroom and thus increase students' language fluency [30]. In addition, the involvement of students in a mission that requires them to discover the proper use of language in different social situations, such as giving written and oral presentations, provides opportunities to demonstrate students' abilities to put their knowledge into practice [31].

PBL focuses on achieving the main goals through enabling students to reproduce languages, develop different skills, and apply and adapt what they already know [29]. Through this reproduction, students develop their knowledge and skills to incorporate language learning and inter-cultural understanding in order to connect learning to the real-world [32]. All of the previous, again, points to project-based learning as encouraging the development of life-skills, and thus encouraging sustainable education. 


\subsection{Research Goals, Rationale, and Questions}

The study aimed to understand the role of project-based learning in developing students' life skills, through implementing PBL in a public school. This research focuses on the following life skills: students' personal and collaborative skills, students' selforientation skills, and students' reliability and collective responsibility. In this study we aim to answer the following overarching research question:

What is the role of project-based learning in developing students' life skills in a language class?

This study is expected to contribute to the field of education in terms of developing students' life skills in the frame of language learning. The projects used in this research aimed to achieve the course objectives through inquiry by offering real problems for students to work on. These problems represented real life problems and required students to use different skills and abilities to arrive at the best solution possible. This kind of project is expected to enhance the life skills needed to decrease the gap between what students learn and what they use in their life. This expectation is in line with Meyer [33], who points at project-based learning as developing life skills. This is achieved through collaboration, as, when students engage in solving real-world problems, their engagement encourages inquiry that leads to deep learning. A problem-solving situation in project-based learning necessitates the employment of critical skills [33]. All of the previous processes are expected to promote the life skills of students. Thus, it is clear that research is needed to study the development of life skills in a project-based learning environment.

The previous argument is especially true of language learning. Grant [34] emphasizes that project-based language teaching "provides a number of potential language learning benefits through opportunities for authentic meaningful language use". The present research attempts to verify this issue when it considers the development of life-skills in project-based language learning.

\section{Materials and Methods}

\subsection{Research Context and Participants}

The research was conducted in the frame of an initiative of the participating school that it suggested to the Ministry of Education as part of the yearly initiatives of the school. The first three authors are supervisors in the Ministry of Education, and they found the initiative interesting and worth studying. They approached the school administration, asking for permission to study the effects of this initiative on students' life skills. After the school administration agreed, they administered a formal consent form to participate in the research to the teacher, the students, and their parents. The parents of two students did not agree for their children participate in the research; therefore, their data were excluded from the research.

The research context is an Arabic language class that included a teacher and her students. The teacher, whom we will call Renat, a fictive name, developed a project to teach Arabic lessons for two classes of 80 grade 6 students ( 30 males, 50 females) at an upper primary school in the second semester of 2018/2019. The school was located in the city of Jenin in Palestine. The students were of a low and middle socio-economic status. The project was developed to teach a phenomenon included in the Arabic textbook about child labor. The participants and their parents signed informed consent forms to participate in the research and they agreed that the collected data could be used for research goals only.

The entire data collection process lasted for nearly two months, from September 2019 to December 2019. In the study, the participants were asked to conduct a project on a topic that was part of their Arabic language book. They were allowed to choose their groups members to form 6-10-member groups, and then give their group a name. The groups worked to achieve their goals by conducting their projects, and by distributing roles between group members in order to achieve the group's goals. In the frame of this project, each group was expected to compete with other groups to complete the task successfully. 
In the present research, we used purposive sampling, one of the most common sampling strategies in qualitative research. In this sampling, participants are grouped according to preselected criteria relevant to a particular issue [35], which here is life skills and project-based learning. Categorizing data from the observations, the teacher's documents and the students' documents made us aware of the issues that we needed to inquire about in the interview. Thus, after interviewing the teacher and five of the students, we arrived at theoretical saturation (the point in data collection when new data does not bring additional insights to the categories related to the research questions) [35].

\subsection{Data Collection Tools}

Four data collection tools were used in this research. Each one of these tools was used to collect data on the different issues related to the role of project-based learning in developing students' life skills. These tools were a semi-structured interview with the teacher and the students, observation of the students while working on projects in the class, texts of the teacher's reflections, and the materials of the students' projects.

Data collection lasted for two months, from late September 2019 to December 2019. The following three tools were included in this case: observations of students' class activities, which were recorded using video recordings, a 45-minute interview with the teacher, and 30-minute interviews with five of the students. The interviews were recorded using a voice recorder, and the collection of teacher's and students' documents.

\subsubsection{Interview}

According to Cohen et al. [36], an interview can be used as "an explanatory device to help identify variables and relationships". For this reason, interviews were conducted with the teacher and students who were involved with project-based learning in the frame of Arabic language education.

\subsubsection{Observation}

Class observation was used to provide an opportunity to "collect large amounts of rich data on the participants' behavior and actions within a particular context" [37]. In this study, the researchers used video recordings to record detailed descriptions of the class. The observation focused on the students' use of life skills, such as the communications of students with each other and with their teacher, students' confidence in themselves and their colleagues, and students' differentiation.

\subsubsection{Teacher's Documents}

The teacher took field notes while conducting the projects, then she wrote her reflection on the experience as well as her students' experiences in the frame of the specified project.

\subsubsection{Students' Documents}

Different documents were collected from the students, such as their stories and reports regarding their experiences and activities in the frame of the specified project.

\subsection{Data Analyses Tools}

Thematic analysis with deductive reasoning was considered the most appropriate for this study, as it seeks to discover knowledge using interpretation. Data from observation, interviews, and documents were transcribed and categorized into different themes based on the conceptual framework underscoring the themes, namely students' life skills. Here, the conceptual framework was developed by the author of [6] and included three types of skills. The first type is interpersonal and collaborative skills. This type of skill includes themes such as the learner's ability to communicate, the learner's ability to develop positive social relationships, and the learner's ability to collaborate with others to achieve common goals. The second type is self-directed skills. This second type includes themes such as addressing the learner's ability to identify learning goals, planning to achieve learning 
goals, managing time and effort to achieve learning goals, evaluating learning outcomes and outputs, and identifying their strengths and weaknesses using an adopted strategy or method. The third type of skill is the skill of reliability and collective responsibility. This third type of skill includes themes such as focusing on the ability of learners to take responsibility for their own learning, focusing on the ability of learners to play a role, and focusing on the ability of the learners to collaborate in order to achieve the goal. Table 1 shows an example of each one of the previous theses. Table 1 helps to show how we used deductive reasoning in analyzing the development of the students' life skills as a consequence of their engagement with project-based learning.

Table 1. Examples on life skills' themes.

\begin{tabular}{|c|c|c|}
\hline Category & Themes & Examples on Themes \\
\hline \multirow{3}{*}{ Interpersonal and collaborative skills } & Communicate & $\begin{array}{l}\text { We communicated using a mobile phone } \\
\text { to decide concerning the project. }\end{array}$ \\
\hline & Engage in social relations & $\begin{array}{l}\text { The project increased our knowing } \\
\text { each other. }\end{array}$ \\
\hline & Collaborate to achieve common goal & $\begin{array}{l}\text { We collaborated inside and outside the } \\
\text { classroom to successfully carry out the } \\
\text { project. }\end{array}$ \\
\hline \multirow{5}{*}{ Self-directed skills } & Identify learning goals & $\begin{array}{l}\text { The group discussed the sub-goals to } \\
\text { achieve the final goal. }\end{array}$ \\
\hline & Plan to achieve learning goals & $\begin{array}{l}\text { The group planned the sequence of } \\
\text { actions that lead to achieving the } \\
\text { project goal. }\end{array}$ \\
\hline & $\begin{array}{l}\text { Manage time and effort to achieve } \\
\text { learning goals }\end{array}$ & $\begin{array}{l}\text { It was important to manage our steps } \\
\text { carefully in order to achieve our goals. }\end{array}$ \\
\hline & Evaluate learning outcomes and outputs & $\begin{array}{l}\text { The group needed to develop a method } \\
\text { to evaluate the project's outcomes. }\end{array}$ \\
\hline & $\begin{array}{l}\text { Identify strengths and weaknesses in the } \\
\text { strategy }\end{array}$ & $\begin{array}{l}\text { The teacher's evaluation of the other } \\
\text { group's strengths and weaknesses gave } \\
\text { us ways to evaluate our own ones. }\end{array}$ \\
\hline \multirow{3}{*}{$\begin{array}{l}\text { Skills of reliability and collective } \\
\text { responsibility }\end{array}$} & Take responsibility for own learning & $\begin{array}{l}\text { The project helped us develop skills of } \\
\text { taking responsibility of our learning. }\end{array}$ \\
\hline & $\begin{array}{l}\text { Be able to play a role in the activity of } \\
\text { the group }\end{array}$ & $\begin{array}{l}\text { It was crucial for the group to help each } \\
\text { member carry out the role assigned to } \\
\text { them. }\end{array}$ \\
\hline & Be able to collaborate to achieve the goal & $\begin{array}{l}\text { We taught ourselves to collaborate with } \\
\text { each other, this collaboration was crucial } \\
\text { for the success of the project. }\end{array}$ \\
\hline
\end{tabular}

\subsection{Validity and Reliability}

To ensure the validity and reliability of the study, the researchers discussed the themes and subthemes before approving the final themes. To ensure reliability and validity of data analysis, each researcher worked alone, transcribed $25 \%$ of the interviews and observations, and coded them. Holsti's method, which is a variation of percentage agreement, gave a percentage agreement of $92 \%$, which is a good score for qualitative research [35].

\section{Results}

The study aimed to reveal the role of project-based learning (PBL) in developing students' life skills. Data were collected from the analysis of the teacher and the students' documents, as well as the observations that took place during the implementation of the projects. We describe below the life skills that were developed through one project in which the students were engaged. 


\subsection{Planning the Project as an Opportunity to Develop Communication Skills}

Renat, the Arabic language teacher, started the project by introducing a problem of child labor by using photos from a local newspaper. These photos showed children wearing old clothes, looking tired, and engaging in selling commodities in the market. The teacher requested the students to discuss the photos. During the discussion, the students proposed the need for implementing a campaign to alert people's awareness to the dangers of child labor. Salam, one of the students who we interviewed said: "The photos of the child labor intrigued us to discuss the options of making people aware of this unbearable situation. This led us to suggest a project that tries to take care of people's ignorance".

The teacher divided the students into groups to implement an awareness campaign that alerts people on the dangers of child labor, where each group chose a name such as the Violet Glow Group and the Childhood group. This was the first step of developing communication skills between groups. Renat, the Arabic language teacher, said: "I assigned different tasks for the groups; such as making interviews of working children. Each group discussed and suggested other activities, such as playing plays about the phenomenon, and writing short stories and poetry". Amin, one of the interviewed students said: "We planned to design awareness leaflets, photo albums, and brochures showing the dangers of child labor".

\subsection{Carrying Out the Project as an Opportunity to Develop Communication Skills}

The groups were working on their tasks, developing the skills of cooperation, communication, respect, and confidence, while the teacher was facilitating their learning and their participation in data collection to complete the campaign. The groups communicated through a social communication network, and each group collaborated with the teacher to facilitate the follow-up work on the project, which developed the communication skills between the students and the teacher, and between the students themselves. Renat, the Arabic language teacher, said: "I discussed with the students the most appropriate criteria for evaluating the tasks of the project such as the story, play, song and interviews. The standards were drafted and then developed with the students until they reached the final criteria to be used in the evaluation of the students' work". Amir, one of the interviewed students said: "We arrived at an agreement with the teacher regarding the evaluation of our work. This agreement reinforced our sense of justice, transparency and self-evaluation skills". This shows the role of classroom agreements in supporting the decision-making skills of students, which are important personal skills for individuals.

The teacher described the effect of the project on students' communications by saying: "Some students were not near to each other, they motivated to visit each other to discuss their task, and even in the school their relations started from the discussion of the project problems and continued to become a friendship". Social relationships developed between students in and beyond school. Amir said: "We decided to make visits to solve the problems we face during the implementation of the tasks. We also met inside the school. This enhanced our communication skills". In addition to that, communication between the students and their teacher was enhanced as a result of changing the teachers' role, which was to support students, guide them, and take care of students' personalities and talents; this contributed to discovering students' abilities and helped them to develop themselves. Renat said: "I became closer to my students discovered some students who could have been marginalized academic achievement, I have discovered hobbies of some students". The teacher also focused on the role of electronic communication with her students, she said: "After time through Messenger, I tried to motivate my students, ask them about their tasks, remind them with the deadline and offer my help anytime." This kind of communication has deepened the relationship between the students and their teacher.

The teacher reinforced the school's communication with the community by informing the local community about what the students were doing. She invited an expert in the subject from the community to give a lecture to the students about child labor and answer their questions on the subject. The students summarized the causes and implications 
of child labor and obtained clear statistics on this phenomenon to enhance the students' communication with the community. This enriched the students' skills to communicate with the community, as well as their confidence to perform this communication. In addition, the journals designed by the students were hanged on the boards of the school hall, and some leaflets were distributed to school students. This has enhanced the marketing skills of participating students, as well as their skills to share their products with their school mates.

\subsection{Carrying out the Project as an Opportunity to Develop Self-Confidence and Self-Direction Skills}

The students were engaged in carrying out the processes of the campaign, while the role of the teacher was directing, facilitating, and following-up these processes to give constructive feedback and help students to communicate, in addition to the division of roles according to the students' talents and abilities. This engagement, as the teachers and students wrote, has trained the students to become self-confident and take collective responsibility. Furthermore, the teacher enhanced the students' self-direction through continuing to evaluate the work of the groups and following them during their work on the play, the story, the interview questions, and the preparation of pictures for the leaflets and the album. On student wrote: "The teacher's feedback encouraged us to look back at our experiences and try to overcome the difficulties that we faced". The teacher tried to make sure that all of the members of the group worked according to his or her tendencies and possibilities, and to make them all know their strengths and weaknesses, which enhanced the skills of the students' self-direction.

Elaborating on the development of students' self-confidence, the student-centered tasks highlighted the students' abilities and made them realize them frequently. They supported each other to achieve success together, and their self-successes contributed to an increase in self-confidence, especially since the project did not rely on parents as before. One student wrote: "Even the introverted students became self-confident that they were not as weak as they thought before". The project helped students to respect each other and become closer without considering the difference between them according to academic achievement.

The tasks were designed to take into account the students' learning styles and intelligences; the tasks required painting, acting, writing, and singing. One student wrote: "In my group, we care that every one has a tendency in this group, some of us are proficient in writing while some mastered the drawing, some of us are proficient in dialogue with people. The student's roles were based on our tendencies and talents." It is clear that PBL helped each student to achieve the learning goals in their own way, with the support of their colleagues.

Elaborating on the development of students' self-direction, PBL helped each student to discover their strengths and weakness while working to solve the problem in different ways, and some students helped other members determine their strengths. Renat also helped her students to do so, she said: "The decision upon the roles between the members of the group was left to the student's own opinion, because every student has his own desire, skills, and what he knows what he mastered, as a teacher I observed then evaluated them. Each student found that he is not weak, vice versa, he became aligned with technology". Salam said: "We wondered about the benefits of the project to our life skills. Before, we were busy only with exams, and did not master the important technological programs. The project made us benefit from each other and exchange experiences, which strengthened us. We learned that there is no weak or strong student, but there is a student who lacks some skills and should work on them". Actually, the differentiation caused by the PBL tasks helped the participating students to know more about themselves and about others; therefore, it was easy to know their strengths and weaknesses.

The supporting environment also extended to peers. Students focused on evaluating each other's work and on providing feedback, thus contributing to peer learning, which helped them to identify their strengths and weaknesses. Renat said: "When the project of each group was presented to the rest of the groups, the groups benefited from the 
feedback given for this group. When the weaknesses were discussed, they were taken care of by the other groups, and when the strengths were discussed, they were used by some groups to strengthen their work". This support added to the development of the students' self-direction.

\subsection{Carrying Out the Project as an Opportunity to Develop Formal Behavior Skills}

The teacher communicated with the administration and parents, who showed interest in the project's idea because of its importance to the community, to enable the children to succeed in carrying out the project. The parents supported their children, either by facilitating the students' communication with a child protection network coordinator, or the head of the family affairs department in the governorate, who accompanied the students during the interviews with the children working in the markets. Through this process, students were more aware of the legal issues related to interviewing young people, accountability, and ensuring the safety of young interviewees. This also strengthened communication skills between the students and the community. One student wrote: "We distributed the leaflets that we designed to shopkeepers, highlighting the disadvantages of child labour, and emphasizing the importance of the problem and its seriousness to society. Sometimes, we held conversations with the shopkeepers. This enhanced our communication with those shopkeepers". Again, as the student's text shows, carrying out the project enhanced the students' social communication skills with the local community.

\subsection{Carrying Out the Project as an Opportunity to Develop Collective Responsibility}

Analysis of the documents of the teacher and students in addition to the interviews and films showed that PBL enhanced the reliability and collective responsibility by transferring the responsibility of learning from the teacher to the learner. The students took responsibility for learning the content, and the responsibility of other members' learning. It also emerged that the students divided roles between them, relied on the integration of roles among them to achieve the goals, and exchanged their experiences and provided each other with feedback. The teacher said: "I was surprised from a student with a medium academic achievements, applied the Scratch program to turn a story to animation and give the characters using his voice, this story was written by a student with excellent academic achievement, the first student didn't master writing, while the second didn't master Scratch program a third student said: I will share the drawing, I want to draw the characters of the story".

The teacher followed up the students' work and supported them when needed by helping them to use new technologies. This learner centered approach helped the students to develop reliability and collective responsibility, and thus cognitive and technological skills.

To sum up, the findings show that PBL has developed personal and cooperative skills, self-orientation skills, and reliability and collective responsibility skills as a result of tasks that promote differentiation to ensure that each student works according to his or her ability, in addition to the development of communication due to the demands of the tasks including teamwork and the integration of abilities. The role of the teacher in this Arabic language classroom also helped to transfer the learning responsibility from teachers to students and that enhanced their collective responsibility skills. As a result, the students life skills were developed.

\section{Discussion, Conclusions and Recommendations}

Project-based learning is being suggested as a strategy that enriches students' learning (e.g., [38,39]). This study aimed to examine the role of PBL in developing students' life skills in a language classroom. The research results indicated that PBL contributed to developing students' life skills through enhancing their personal and cooperative skills, including their communication skills, the students' confidence in themselves and in their colleagues, and their self-orientation skills related to the differentiation and determination of their strengths and weaknesses. In addition, by supporting each other to achieve learning goals, 
the students developed their reliability and collective responsibility skills. The findings of the present study indicate that PBL could result in educational habits that become sustainable life habits [40]. Below, we discuss the contribution of PBL to the students' development of their life-skills in light of social constructivism, multiple intelligences, and sustainable education.

\subsection{Discussing the Contribution of PBL to the Development of Students' Life-Skills in Light of Social Constructivism Theory}

The first theory, social constructivism theory, was reflected when students worked collaboratively to implement the project tasks. At these moments they worked as teams and communicated with each other to achieve the objective of solving the task and presenting the results to the other groups, which affected the students' cooperative skills. The students also took responsibility for their language learning when the teacher gave them tasks to be solved independently without relying on her, where her role became advising and monitoring. This taking of responsibility by the students is part of project-based learning. Sudadi [41] says that students who engaged in project-based learning take responsibility for their own learning and, thus, become life-long learners. This claim points to the relationship between project-based learning and the development of life skills, as life skills are needed for life-long learning [42]. Moreover, this taking responsibility could indicate the development of different life skills as self-regulation. Carpenter and Pease [43] found that self-regulation and collaboration contribute to the ability to make decisions. In addition, this taking responsibility could positively affect students' personal skills, self-regulation, reliability, and collective responsibility skills $[15,18]$. The social interactions of students who communicated with each other in and outside the class to complete the tasks provided a social context in which the students were responsible for their learning $[16,44]$. These social interactions resulted in the participants being responsible for children in their community, as, after interviewing children in society and hearing their problems, the student's tried to help the children they interviewed, which developed the students' collective responsibility skills. These processes of interaction in society indicate social partnership [45].

\subsection{Discussing the Contribution of PBL to the Development of Students' Life-Skills in Light of Multiple Intelligences Theory}

The second theory is multiple intelligences theory, where the project provided environments that met the multiple intelligences of students through a differentiation of tasks that required drawing, singing, meeting others, playing roles, collecting pictures, or designing posters. The tasks fitted different students' abilities rather than depending on their achievement levels. The students in groups respected the different abilities of their peers, being aware that it is important to draw pictures or use professional technological programs. The members of a group complemented each other's intelligence to make progress in the project, which enhanced personal and cooperative skills, self-orientation skills, in addition to reliability and collective responsibility ones.

In addition to the argument above, Bas [46] argues that project-based learning assists learners in developing all of their intelligences, which makes learning a part of living, not just a preparation for it. This indicates that project-based learning through multiple intelligences can promote learners' life skills. Moreover, Ofrim-Stăncună [47] found that the project-based assessment could provide a multiple intelligences environment that was successful in supporting the effective internalization of linguistic concepts and in-depth language learning.

\subsection{Discussing the Contribution of PBL to the Development of Students' Life-Skills in Light of Sustainable Education}

The steps that PBL in the language classroom followed in this case show how the teacher started from the curricula included in the textbook, and developed it into a real problem, asking her students to solve this problem. This is similar to a real-life situation in which an individual or a group encounters a problem that they need to solve. They solve 
the problem by utilizing different interdisciplinary and multidisciplinary resources [48]. Thus, project-based learning provided situations that the students needed to solve by using different resources and by communicating with the community. Moreover, inviting an audience from the school and the community made the described project similar to real-life situations. Here too, the students were involved in sustainable education as they learned how to act and interact with themselves and with the community. Moreover, working with the community constituted a kind of partnership with it. This partnership provides the students with enriched curricular and extracurricular experiences and explorations that positively affect students' learning and their knowledge, skills, and talents [49]. We can say that this partnership also increases students' life skills.

\subsection{Conclusions and Recommendations}

The present research results showed that PBL is a viable context for developing students' life skills in the language classroom through providing an environment that motivates them to work in teams, communicate with each other, respect each other, and determine ones' strengths and abilities. PBL also supports the process of considering differentiation between individuals, which positively impacts students' engagement, motivation, and allows them to work collaboratively. All of the previous potentialities of PBL not only provided context for developing the students' life skills, but also provided context for sustainable education that prepares the students for appropriate life functioning.

Furthermore, PBL allows teachers' scaffolding, through goal clarification, facilitation, and guidance. This scaffolding helps the students in direct and indirect ways. In the present research, the teacher's scaffolding for a group helped other groups pay attention to their strengths and weaknesses. This highlights the importance of teacher's scaffolding not only in a face-to-face classroom, but also in a project-based one. Thus, teachers are encouraged to oversee the groups' work, but not to intensify the supervision, to ensure that the group's work leads to the development of the autonomy that is part of life skills, especially self-directed skills. Here, the notion of the Zone of Proximal Development of Vygotsky could advise teachers regarding the extent of their scaffolding [50]. Teachers need to assess the zone between the skills and knowledge they actually possess and those they need to possess in order to carry out a project and base their scaffolding on this zone.

The study explained how PBL and its characteristics, as explained by the social constructivist and multiple intelligences theories, develop students' life skills, but more than that, it provides a context for sustainable education. This argument is supported by the researchers pointing at project-based-learning as providing an environment in which sustainable education is satisfied [51].

Depending on study findings, PBL is recommended as a teaching method in the language classroom, which will result in the development of students' life skills, as the present research suggests. For PBL to succeed in a language classroom, a training program for language teachers to develop their competencies in designing projects related to the community and its problems is recommended to ensure that the school becomes a community institute. All of the training programs need to focus on sustainable education [52].

\section{Limitations and Ethical Considerations}

\subsection{Limitations}

This study is a qualitative one that used three data collecting tools, specifically interviews, observation, and the teacher's and students' writings on carrying out the project. More research needs to be conducted on the issue of project-based learning and life skills, the relationship between them, and their relationship to sustainable education. More research needs to be conducted on sustainable education in language learning using different methodologies, especially quantitative and qualitative methodologies.

The present study was performed in an Arabic language classroom, where similar studies in other language classrooms could verify the findings of the present research. 


\subsection{Ethical Considerations}

The present study involved an ethical issue, which is children's work. We administered informed consent forms to the participants (the teacher and her students) to participate in the research. The consent form was written in a language easily understood by the participants, which minimised the possibility of misunderstanding. The participants were given sufficient time to consider participation in the research. Observations were conducted for the classroom activity only. Specifically, we did not perform observations of the students' communication with the children working in the city market. The goal of the research was to study project-based learning and its influence on life skills as part of sustainable education. The research goal was not to study child labour; therefore, we did not collect data on this social issue.

Similar projects could be conducted in the classroom, not only in in a language classroom. The ethical issues studied in the classroom are of great importance as they open students' eyes to the inequalities in society, which could encourage them to try changing these inequalities to make a more equitable society.

Author Contributions: Conceptualization, D.G.W., E.A.N. and A.F.S.; methodology, D.G.W., E.A.N., A.F.S. and W.D.; formal analysis, D.G.W., E.A.N. and A.F.S.; writing, D.G.W., E.A.N., A.F.S., M.A. and W.D.; review and editing, M.A. and W.D.; supervision, W.D. All authors have read and agreed to the published version of the manuscript.

Funding: This research received no external funding.

Informed Consent Statement: Informed consent was obtained from all subjects involved in the study.

Acknowledgments: We thank the teacher, the school who agreed to participated in the study.

Conflicts of Interest: The authors declare no conflict of interest.

\section{References}

1. Jiménez, B.; Tatiana, V. Communication skills training with pictograms to improve reading and writing skills of colombian children with speech and language impairments. Int. J. Interdiscip. Educ. Stud. 2020, 15, 61-72. [CrossRef]

2. Portela, L.; Pino-Juste, M. Analysis of the processes of change in schools: From the culture of complaint to the culture of the transformation. Int. J. Interdiscip. Educ. Stud. 2020, 15, 83-98. [CrossRef]

3. World Health Organization. Life Skills Education for Children and Adolescents in Schools; World Health Organization: Geneva, Switzerland, 1994.

4. $\quad$ Dinesh, R.; Belinda, R. Importance of life skills education for youth. Indian J. Appl. Sci. 2014, 4, 92-94.

5. Boss, S.; Larmer, J.; Mergendoller, J.R. PBL for 21st Century Success; Buck Institute for Education: Novato, CA, USA, 2013.

6. Global Partnership for Youth Employment. Enhancing Life Skills for Youth Employment: A Practical Guide to Designing Quality Programs; International Youth Foundation: Baltimore, MD, USA, 2014. Available online: https://www.iyfnet.org/sites/default/ files/library/Strengthening_Life_Skills_For_Youth_Arabic.pdf (accessed on 1 May 2021).

7. Ledward, B.; Hirata, D. An Overview of 21st Century Skills 2011; Kamehameha Schools-Research, Pacific Policy Research Center: Honolulu, HI, USA, 2011.

8. Dewey, J. My Pedagogic Creed. John Dewey's famous declaration concerning education. Sch. J. 1897, 5, 77-80.

9. Peterson, B. Uncovering the Progressive Past: The Origins of Project Based Learning. Unboxed 2012, 8 . Available online: https://gse.hightechhigh.org/unboxed/issue8/uncovering_the_progressive_past (accessed on 1 May 2021).

10. Roessingh, H.; Chambers, W. Project-based learning and pedagogy in teacher Preparation: Staking out the theoretical mid-ground. Int. J. Teach. Learn. High. Educ. 2011, 23, 60-71.

11. Daher, W. Mathematics learning community flourishes in the cellular phone environment. Int. J. Mob. Blended Learn. (IJMBL) 2010, 2, 1-17. [CrossRef]

12. Daher, W. Student Voice in the Mobile Phone Environment: A Grounded Theory Approach. Int. J. Mob. Blended Learn. (IJMBL) 2017, 9, 12-23. [CrossRef]

13. Daher, W.; Anabousy, A.; Jabarin, R. Metacognition, positioning and emotions in mathematical activities. Int. J. Res. Educ. Sci. (IJRES) 2018, 4, 292-303. [CrossRef]

14. Thao, T.N. Developing Important Life Skills through Project-Based Learning: A Case Study. Norm. Lights J. 2017, 11, 109-142.

15. Wurdinger, S.; Jennifer, R. Teaching important life skills through project based learning. Main Issues Pedagog. Psychol. 2014, 5, 53-57. 
16. Nassir, S.M. The Effectiveness of Project-Based Learning Strategy on Ninth Graders' Achievement Level and Their Attitude towards English in Governmental Schools-North Governorate. Master's Thesis, The Islamic University of Gaza, Gaza, Palestine, 2014.

17. Barron, T. Doing with understanding: Lessons from research on problem—and project—based learning. J. Sci. 1998, 7, $271-311$.

18. Bivens, F.; Moriarty, K.; Taylor, P. Transformative education and its potential for changing the lives of children in disempowering contexts. IDS Bull. 2009, 40, 97-108. [CrossRef]

19. Walshe, N. An interdisciplinary approach to environmental and sustainability education: Developing geography students' understandings of sustainable development using poetry. Environ. Educ. Res. 2017, 23, 1130-1149. [CrossRef]

20. MacLeod, M.; van der Veen, J.T. Scaffolding interdisciplinary project-based learning: A case study. Eur. J. Eng. Educ. 2020, 45, 363-377. [CrossRef]

21. Öhman, J.; Sund, L. A Didactic Model of Sustainability Commitment. Sustainability 2021, 13, 3083. [CrossRef]

22. Fortune, T.; Borkovic, S.; Bhopti, A.; Somoza, R.; Nhan, H.C.; Rangwala, S. Transformative learning through international project-based learning in the global south: Applying a students-as-partners lens to a "high-impact" Capstone. J. Stud. Int. Educ. 2019, 23, 49-65. [CrossRef]

23. Lavrysh, Y. Transformative learning as a factor of lifelong learning by the example of Vocational Education in Canada. Порівняльна Професійн $а$ Педагогіка 2015, 5, 62-67. [CrossRef]

24. Anand, D.; Anuradha, R.K. Life skill based education for sustainable future of adolescent girls. Int. J. Home Sci. 2016, 2, $213-217$.

25. Osatananda, V.; Salarat, P. The tolerance of English instructors towards the Thai accented English and grammatical errors. Indones. J. Appl. Linguist. 2020, 9, 685-694. [CrossRef]

26. Triastuti, A.; Riazi, M. Indonesian EFL teachers' content conceptualization and course organization: A portray of text-based teaching. Indones. J. Appl. Linguist. 2020, 9, 526-535. [CrossRef]

27. Nurkamto, J.; Saleh, M. Integrating life skills in English language teaching (ELT): Strategies, problems and their possible solutions. J. Lang. Lit. 2013, 12, 75-91.

28. Kalabzová, M. The Application of Project-Based Learning in the English Classroom. Master's Thesis, University of West Bohemia, Pilsen, Czech Republic, 2015. Unpublished.

29. Laverick, E.K. Project-Based Learning. ELT Development Series; TESOL Press: Alexandria, VA, USA, 2018.

30. Mikulec, E.; Miller, P. Using Project-Based Instruction to Meet Foreign Language Standards. Clear. House 2011, 84, 81-86. [CrossRef]

31. Byram, M.; Gribkova, B.; Starkeym, H. Developing the Intercultural Dimension in Language Teaching: A Practical Introduction for Teachers; Council of Europe: Strasbourg, UK, 2002.

32. Meyer, K.A. Students' perceptions of life skill development in project-based learning schools. J. Educ. Issues 2015, 2, 91-114. [CrossRef]

33. Grant, S. Implementing project-based language teaching in an Asian context: A university EAP writing course case study from Macau. Asian-Pac. J. Second. Foreign Lang. Educ. 2017, 2, 1-13. [CrossRef]

34. Saunders, B.; Sim, J.; Kingstone, T.; Baker, S.; Waterfield, J.; Bartlam, B.; Burroughs, H.; Jinks, C. Saturation in qualitative research: Exploring its conceptualization and operationalization. Qual. Quant. 2018, 52, 1893-1907. [CrossRef]

35. Cohen, L.; Manion, L.; Morrison, K. Research Methods in Education, 6th ed.; Routledge: London, UK, 2007.

36. Mackey, A.; Gass, S. Second Language Research: Methodology and Design; Lawrence Erlbaum Associates Publisher: London, UK, 2005.

37. González-Domínguez, J.; Sánchez-Barroso, G.; Zamora-Polo, F.; García-Sanz-Calcedo, J. Application of Circular Economy Techniques for Design and Development of Products through Collaborative Project-Based Learning for Industrial Engineer Teaching. Sustainability 2020, 12, 4368. [CrossRef]

38. Wróblewska, D.; Okraszewska, R. Project-Based Learning as a Method for Interdisciplinary Adaptation to Climate Change--Reda Valley Case Study. Sustainability 2020, 12, 4360. [CrossRef]

39. Pérez-Ferra, M.; Quijano-López, R.; García-Martínez, I. Impact of Educational Habits on the Learning of 3-6 Year Old Children from the Perspective of Early Childhood Education Teachers. Sustainability 2020, 12, 4388. [CrossRef]

40. Sudadi, S. The implementation of project-based learning to improve recount essay writing of the eighth graders. J. Pendidik. Pengajaran 2020, 3, 47.

41. Saravanakumar, A.R. Life Skill Education through Lifelong Learning; Lulu Publications: Raleigh, NC, USA, 2020.

42. Carpenter, J.P.; Pease, J.S. Preparing students to take responsibility for learning: The role of non-curricular learning strategies. J. Curric. Instr. 2013, 7, 38-55. [CrossRef]

43. Gori, E.; Romolini, A.; Fissi, S.; Contri, M. Toward the Dissemination of Sustainability Issues through Social Media in the Higher Education Sector: Evidence from an Italian Case. Sustainability 2020, 12, 4658. [CrossRef]

44. Cox-Petersen, A. Educational Partnerships: Connecting Schools, Families, and the Community; SAGE Publications: Washington, DC, USA, 2010.

45. Bas, G. Integrating Multiple Intelligences in ESL/EFL Classrooms. Int. TESL J. 2008, 14, 1-5. Available online: https:/ files.eric. ed.gov/fulltext/ED503870.pdf (accessed on 25 April 2021).

46. Ofrim-Stăncună, L.A. A Multiple Intelligences approach 2: Project-based assessment. Procedia-Soc. Behav. Sci. 2014, 128, 504-508. [CrossRef] 
47. Chen, Y.; Daamen, T.A.; Heurkens, E.W.; Verheul, W.J. Interdisciplinary and experiential learning in urban development management education. Int. J. Technol. Des. Educ. 2020, 30, 919-936. [CrossRef]

48. Epstein, J.L.; Sanders, M.G.; Sheldon, S.B.; Simon, B.S.; Salinas, K.C.; Jansorn, N.R.; Williams, K.J. School, Family, and Community Partnerships: Your Handbook for Action; Corwin Press: Washington, DC, USA, 2018.

49. Verenikina, I. Scaffolding and Learning: Its Role in Nurturing New Learners; University of Wollongong: HongKong, 2008. Available online: https:/ / ro.uow.edu.au/edupapers/43 (accessed on 25 April 2021).

50. Lamborn, J. Teaching sustainability using project based learning. In Proceedings of the SSEE 2009: Solutions for a Sustainable Planet, Melbourne Convention \& Exhibition Centre, Melbourne, Australia, 23-24 November 2009; pp. 436-442.

51. Walshe, N.; Tait, V. Making Connections: A conference approach to developing transformative environmental and sustainability education within initial teacher education. Environ. Educ. Res. 2019, 25, 1731-1750. [CrossRef]

52. Sund, L. Facing global sustainability issues: Teachers' experiences of their own practices in environmental and sustainability education. Environ. Educ. Res. 2016, 22, 788-805. [CrossRef] 